\title{
Experimental Organism Malignant Neuroepithelial Carcinoma
}

National Cancer Institute

\section{Source}

National Cancer Institute. Experimental Organism Malignant Neuroepithelial Carcinoma. NCl Thesaurus. Code C124608.

A carcinoma that arises from neuroepithelial tissues of the olfactory epithelium. 